\title{
Social identities and racial integration in historically white universities: A literature review of the experiences of black students
}

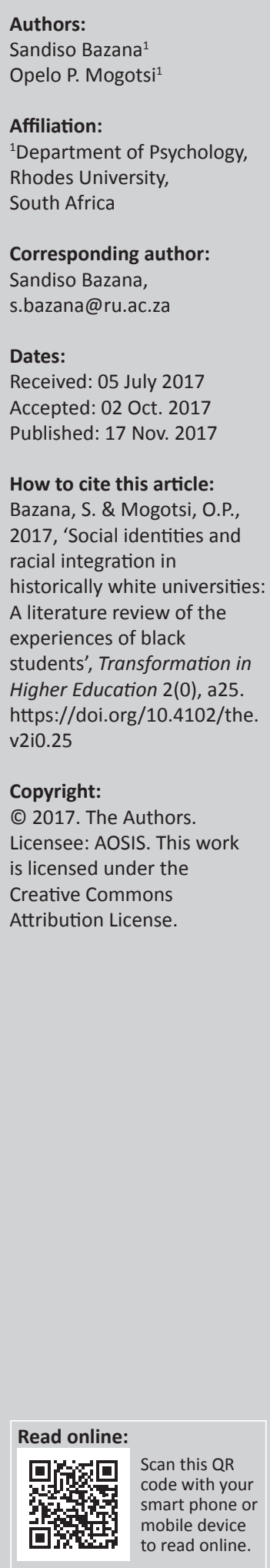

South African government has been promulgating pieces of legislation aimed at ensuring racial integration, especially in higher education, and indirectly enforcing acculturation in historically white universities. Studies have proven that institutional cultures in historically white universities alienate and exclude black students' identities. These students' sense of social identity, which includes culture, heritage, language and traditions, and consequently self-esteem and self-concept, is altered in these institutions. Research has been scant regarding the shape and form that black students' identity assumes when they get to these spaces. Using Tajfel and Turner's (1979) social identity theory and Berry's (2005) theory of acculturation, this article explores the experiences of black students in negotiating their social identities in historically white universities. Evoking Steve Biko's analysis of 'artificial integration' (1986), we hope to illustrate how the 'integration' narrative sought to discard the identity of black students and psychologically enforce a simulation of black students into white-established identities. The study has implications for policy development as we hope to sensitise theoretically the historically white universities to, apart from mere opening of spaces of learning, understand the social identity challenges of black students in these institutions.

\section{Introduction}

This paper seeks to explore existing literature to understand the social identities of black students in historically white universities (HWU). The authors of this study agree with Barroso (2015) that available literature on the identity of black students in South Africa is scant. Moreover, the focus has been on self-identity and cultural identity (Goldschmidt 2003; Mnguni 2000), and rarely social identity. Self-identity has been described as traits and characteristics that define who one is (Leary \& Tangney 2012), while social identity according to Tajfel and Turner (1979) refers to an individual's self-concept as a result of them belonging to a group they identify with and are part of. While some studies have shown that black students have positive identities (Barroso 2015), there was evidence of difficulties with negotiating social identities. This would imply that a positive self-identity does not necessarily result in a positive social identity, therefore making the question around social identity applicable.

The social context of South Africa is discussed in this study. The authors sought to explore the effects of apartheid and colonialism and demonstrate how they contributed to racial segregation in the post-apartheid South Africa. Through the apartheid regime, racial segregation was legalised and people were provided with identification labels (Goldschmidt 2003). Recent research has shown that there is still racial segregation both nationally (The South African Reconciliation Barometer Survey 2010) and in institutions of higher education (Barroso 2015; Pattman 2007; Moodley 2013). Racial segregation in universities is concerning as it hints at lack of real integration and possible social identity challenges for black students who are becoming a majority in these universities in terms of numbers.

Colonialism and apartheid led to both social and economic inequalities. These inequalities have left most black South Africans in marginal communities with high rates of poverty (Withnall 2016). This low economic status is discussed in this study with regard to how it affects black students' social identity in HWU. Adjustment issues are reported to be worse for students whose culture is too different from the culture in these universities (Bojuwoye 2002). The well-being of black students in these universities remains a concerning factor (Young \& Campbell 2014). 
The paper explores HWU and recognises the colonial foundations of these universities. The study will however focus more on the apartheid era socio political occurrences. Using literature review, this paper seeks to explore the existing literature to understand the social identities of black students in HWU.

The history of these universities is briefly discussed, once again demonstrating the effects of apartheid and colonialism. The movement towards decoloniality and transformation in these universities is discussed, including their pitfalls according to the available literature. The culture in these universities is discussed as contributing to the social identity challenges of black students. HWU are reported to be alienating for black students (Hook 2004) contributing to racial segregation even in the post-1994 South Africa.

Frantz Fanon's ideas were used to understand the experiences of black students. A recent study by Barroso (2015), who also used Fanon's ideas to understand black identities in HWU, was used to guide the section in understanding the identity of black students in a historically white university. While understanding these identities, it was also noted that identities of black students are heterogeneous and fluid. A middle-class black identity is highlighted as different and in most cases acceptable compared to identities of black students from lower socio economic status. The social identity theory (SIT) by Tajfel and Turner (1979) and Berry's (2005) acculturation theory were used to understand the social identity of black students in a historically white university. Steve Biko's artificial integration was also discussed to highlight and demonstrate times when this integration is one-sided and therefore artificial.

This study therefore aims to explore the available literature to explore the social identities of black students in HWUs in South Africa. It is relevant to conversations around decolonising higher education in South Africa. As universities are opening access and coming up with policies to transform higher education (Matthews 2015), they should also be aware of the shape and form that the social identities of black students assume when they get to these universities. The main recommendation from this study is that higher education should consider the social identity of black students as they formulate and review and implement transformation policies as well as policies towards decolonisation of higher education. Higher education should be careful that transformation and decolonisation policies do not perpetuate the historical oppression of black students.

\section{Social context of South Africa}

As universities are said to mirror societal experiences (Mnguni 2016), the historical and resulting current social context of South Africa is relevant to understanding the social identity of South African black students in HWU. South Africa is diverse both linguistically (with 11 official languages) and ethnically and culturally (embracing many cultures and customs) (Berg 2012; McKinney \& Soudien
2010). South Africa is also diverse racially with African or black people as the majority in numbers (Africans or black people consist of $80.5 \%$ of the population while white people are $8.3 \%$ and mixed race and Indian people are $8.8 \%$ and $2.5 \%$, respectively) (Statssa.gov.za).

The cultural diversity of the post-apartheid South Africa prompts a move towards multiculturalism (Berry 2005), which Archbishop Desmond Tutu termed the 'Rainbow Nation' (Habib 1997). As much as a movement towards multiculturalism or the concept of a rainbow nation is appreciated, some inequalities of the past cannot be undone by merely referring to the country as 'multicultural' (Matthews 2015) or a rainbow nation. Some of these inequalities were perpetuated by cultural superiority sentiments, which have shaped current South Africa, where white culture has become ethnocentric.

As a result of apartheid practices, black identity was flooded with negative connotations that contributed to the inferiority of black people (Barroso 2015). Being a white person was promoted as being the ideal identity and skin colour was of hierarchical importance (Barroso 2015). The white race remains the dominant and powerful race culturally and economically because of privileges of the past (Matthews 2015). In fact, the economic status of the white race translated to cultural capital that became the quest of the colonised (Mda 1995).

Apartheid in South Africa is therefore an undeniable political period that shaped social interactions (Foster 1991). Racial segregation affected relationships among different race groups, mostly black relationships and white relationships and as a result people formed culture-based interactions and social groups (Foster 1991). Apartheid formed a basis for racial identities, 'black-us' and the 'white-other', through legislation that enforced racial segregation (Barroso 2015). 'By imposing identification labels, the government provided its people with an identity' (Goldschmidt 2003:205). 'Black identity embodied inferiority, submissiveness and dependency on and servitude to whites' (Barroso 2015:40).

As Bhabha (1963) argues in the foreword of The Wretched of the Earth that:

Colonialism, not only physically disarms the colonized subject but robs her of a 'pre-colonial' cultural heritage - and the cultural specific enclaves created by the apartheid government allowed the colonized to regroup on basis of their pre-colonial identities which had arguably been contaminated by the emergence of middleclass status within their 'midst'?, as the colonized group. (p. XX)

In fact starting from colonialism, cultural specific identities were crafted, but the economical upper hand that came through conquest positioned the culture of the colonisers as superior and, therefore, ethnocentric (Crais 1992).

Biko as cited in Hook et al. (2004) observed the destruction of the black person's ability to imagine and apply 'his' logical convictions, because of 300 years of oppressive rule. 
According to Biko, the most potent weapon that a black person could use to remain 'sane' was taken away from him (1986). This potent weapon according to Biko is the mind. The decolonisation project thus far has not free(d) black people from their complex past that not only affected socioeconomic status but also their sense of identity (Barroso 2015). This is critical in understanding the social identity of black students in historically white institutions (HWI) and will be explored later.

The enclaves that were created by the apartheid regime referred to as homelands contributed to the detachment of 'black' groups from other race groups in the country. This created a situation where 'blacks' in those enclaves recurved identities that were informed by first their experiences of economic deprivation, exclusion from the broader South Africa and, most importantly, regrouping based on cultural values (Khunou 2009). This created nervousness and anxiety among black people who dared to step out of their comfortable 'cultural zones' into white-dominated spaces, which is presently required of black students in HWU and South Africa as a whole.

The South African Reconciliation Barometer Survey found that $42 \%$ of South Africans 'rarely' or 'never' speak to someone of a different race group while $60 \%$ 'rarely' or 'never' socialise with people of a different race group (Lefko-Everett et al. 2010). Although possibly outdated, the above results suggest racialised social interactions in the post-apartheid South Africa. Racialised interactions have also been observed in universities (Schrieff et al. 2010). In a study at Rhodes University, social interactions with white students were out of necessity and were found to be associated with discomfort and unease (Barroso 2015). In a different study in the University of KwaZulu-Natal, students were reported to distance themselves from other races (Pattman 2007). A study in Cape Town also showed racialised interactions (Moodley 2013).

Racialised interactions in the general South Africa and universities may indicate unresolved anxieties, as already mentioned, that affect social relations even in HWU. According to Finchilescu et al. (2007), the lack of racial integration is concerning as it hints at a lack of transformation and unity of people of different races. Racialised interactions may affect the social identity development of black students and the way in which they manage or negotiate their social identity in HWU. The lack of integration in universities has been associated with non-acceptance of black students and it is reported to be alienating (Moodley 2013). It can then be concluded, as the outline above suggests, that the historical context of South Africa and the resulting social context may contribute to the challenge of black students in negotiating their social identity as well as racial integration in HWU.

\section{Historically white universities}

The history of racial segregation in higher education in South Africa is important to understand institutions of higher education, especially predominantly white institutions where some black students attend. Firstly, higher education and institutions of learning form a part of the colonial project, and thus these institutions are a symbol of colonialism (Heleta 2016). The National Party came into power in 1948 and made a decision to offer higher education to black students in separate educational institutions (Stellenbosch and Potchefstroom did not accept black students, Rhodes University did the same with exceptions to certain postgraduate classes, while universities of Cape Town and Witwatersrand accepted black students) (United Nations 1967 as cited in Greyling 2007).

The extension of University Education Act in 1959 proposed to have separate universities for black students and white students (United Nations 1967). Because of the bill, white institutions were prohibited from accepting black students. According to Cutten (1987), the bill was an extension of apartheid policy that excluded people according to race. 'A major task of South Africa's new government in 1994 was to promote racial equity in the state education system' (Fiske \& Ladd 2006:2).

Racial equity in educational systems would highlight a racially blind system or a system where there is no exclusion based on race, which prompted the democratic government to make education accessible to all students regardless of their race (Fiske \& Ladd 2006).

Meier and Hartell (2009) state that a racially blind educational system may lead to ignorance of diversity of students in terms of cultural background and the implications of these on learning. A racially blind educational system may also result in an assimilationist approach where 'learners are expected to adapt to the existing character of the school and curricula that have been implemented for a different learner population' (Meier \& Hartell 2009:181).

\section{Black students and some documented social identity challenges}

According to Collins and Millard (2013), HWU were created for a white student population; this results in a dominant white culture that is exclusive of black students (Hook 2004). Studies have proven that institutional cultures in HWU alienate and exclude black students (Steyn et al. 2014). These universities 'culturally alienate outsiders, from the type of activities that are done in residences to the content of the curriculum that is taught' (Mnguni 2016:18).

Approaches to theoretically understand the institutional culture in HWU show the underlying factors that contribute to the othering and exclusion of black students from the dominant culture (Phoenix 2009). These students' sense of social identity, which includes culture, heritage, language and traditions, and consequently self-esteem and selfconcept, gets altered in these institutions. Historically, education contributed to a conflict of cultures (Biko 1986; 
Steyn et al. 2014). Values, customs and practices of the black community were negated in educational institutions (Biko 1978) and continue to be negated in HWU through institutional cultures that favour a white culture.

The institutional culture which favours white cultures, and disadvantages black students, may lead to adjustment difficulties (Steyn et al. 2014). Educational systems are said to prioritise white culture through an institutional culture that alienates specific groups of black students and makes them uncomfortable (Barroso 2015). White culture in this sense can be defined as the types of materials and discourses (Vincent 2015) in HWUs before racial equity in educational systems (Fiske \& Ladd 2006). The character of the university points to institutional culture, which was defined by Vincent (2015) as the tangible (material) as well as intangible (discourse) way of doing things in an institution.

Disadvantaged students are vulnerable to adjustment difficulties (Petersen 2006), especially when the institutional culture is different from their own (Bojuwoye 2002). This may apply to students whose social, economic and cultural background had little or no direct influence of white culture. For instance, dining halls with high tables and the use of forks and knives in Rhodes University dining halls have been observed and questioned in terms of their applicability to black students from rural areas (Macupe 2016).

Education in HWI is said to enforce an assimilationist perspective where black students are assimilated into the existing white culture; this involves the use of the English language, Westernised concepts as well as resources for learning (Pilane 2014). The use of English has been implicated in problems with learning (Moodley 2013). Black students are assumed to readily assume this 'culture' and integrate into the existing system of learning that was historically created for white students, argue Collins and Millard (2013).

Language has been identified as a potential barrier to performance. Participants in Moodley's (2013) study indicated that with their first language being non-English, being taught by white lecturers could be a challenge. Participants also added that African accents were associated with 'stupidity', leading to reluctance to participate in class discussions even if they added to one's course mark (Moodley 2013). In another study in Cape Town, black clinical psychology students reported their struggle with feeling pressured to 'talk white' and 'write white' during their training (Kleintjes 1991). Using the English language is said to increase one's sense of belongingness (Gibson 2012), which makes failure to speak or use English alienating for black students. A negative connotation associated with African accents as well as challenges experienced with writing and speaking in English can lead to black students feeling alienated in South Africa's higher education but especially in HWU.

In a study in the Witwatersrand University, Rafaely (2014) makes us aware of the impact of the proficiency in English in selection into the master's in clinical psychology programme.
Students who are more proficient in the use of the English language are said to be better able to express themselves and make contributions to discussions (Rafaely 2014). Students who find it easy to express themselves in English are mostly white students and black students who attended private schools before coming to university. This therefore makes a link between English proficiency and socioeconomic status (Raefely 2014). Only socioeconomically advantaged black students were reported to stand a chance to be accepted into the postgraduate psychology programme (Raefely 2014).

In Moodley's (2013) study, white students were associated with privilege. White students were reported to use laptops and iPads, while some black students needed to use school computer labs. Access to laptops is said to have a positive impact on learning (Righi 2012). Black students without laptops may therefore be academically disadvantaged. It was also highlighted that because students from underprivileged communities are not familiar with or cannot afford supportive resources such as seeing a psychologist, they may perform poorly academically (Moodley 2013).

Poor academic performance has already been mentioned as a consequence of adjustment problems (Steyn et al. 2014), which black students may experience because of several factors that have already been discussed above. In fact, the National Planning Commission reports that 'race remains a major determinant of graduation rates in our higher education institutions' (NPC 2011:16). Furthermore, the completion rate for black students is less than half of the completion rate of white students and the figures are particularly low where first generation students are involved; only one in five graduated in the required time (NPC 2011). Steyn et al. (2014) associated this scourge of low throughput rate with unique social, educational, cultural and economic background experiences of 'black' students, which this paper seeks to understand.

If the institutional culture in HWI is unwelcoming of black culture and the identity of black students, then it continues to reproduce the discourses of an 'inferior black' and an 'ideal white'. A black man whose identity has not been freed from negative connotation and inferiority (Barroso 2015) will surely be challenged in a space that fosters a white culture, devaluing blackness. Any attempt to deinstitutionalise HWI should consider this. A historical culture that contributes to the inferiority of blackness plus an unwelcoming institutional culture in HWI encourages mimicry and the dilemma that comes with it. Moore (2005) refers to this as a mental conflict that can be anxiety-provoking for a young black student.

'As the historically white universities have widened access, the focus has inevitably been on academic throughput rather than on psychological wellbeing' (Young \& Campbell 2014:362). However, resulting historical disadvantages can hinder the psychological well-being of black students (Young \& Campbell 2014). An unwelcoming institutional culture in HWU (Steyn et al. 2014), as well as the resulting consequences on the psychological well-being of black 
students (Young \& Campbell 2014), makes the question of social identity relevant in HWI of higher learning in postapartheid South Africa.

\section{Decolonisation and transformation in higher education}

The challenges of black students in HWI have led to the movement towards decolonising the curriculum in higher education, following the Rhodes Must Fall protests in 2015 (Heleta 2016). Professor of Genetics (Brenda Wingfield) in the University of Pretoria defined decolonisation of education as the independence of a nation in producing and acquiring knowledge, values and skills (Wingfield 2017.). While Wingfield (n.d.) gave evidence for local research in science and technology (African epistemology), she also gave insights into decolonising education. According to Wingfield (n.d.), decolonising knowledge does not mean removing all knowledge that is Western but it means supplementing it with, and recognising, African knowledge.

Supplementing and recognising African knowledge is still a challenge in HWI (Matthews 2015). 'While all universities have had new policies and frameworks that speak about equality, equity, transformation and change, institutional cultures and epistemological traditions have not considerably changed' (Heleta 2016:2). Universities of higher education are reported to be Western in that the methods and the ways of teaching still reflect the Eurocentric epistemology (Mbembe 2016). In an interview with one of the students at the University of Cape Town during protest, Evans (2016) sought to understand what decolonisation is and why universities should be decolonised. The interviewee reported that the curriculum 'dehumanizes black students' in that it required them to use Western epistemology as a standard way of thinking and looking at the world (Evans 2016).

Higher education is not only based on Eurocentric epistemology, it is also reported to be colonial (Heleta 2016). A Eurocentric, colonial curriculum is one that disregards and patronises African views while reinforcing Western views (Heleta 2016). 'There is something profoundly wrong when, for instance, syllabuses designed to meet the needs of colonialism and Apartheid should continue well into the liberation era' (Mbembe 2016:32). 'Whereas political freedom was achieved in 1994, many structural imbalances, inequalities and injustices remain stumbling blocks for the emancipation of black South Africans' (Heleta 2016:1).

In addition to challenges in transforming and decolonising higher education, white men remain dominant in these universities (SAHR Report 2016). Transformation of the demographics of academic staff in HWU remains a challenge because the number of black professors and mixed race professors is still insufficient (SAHR Report 2016). Keeping the history of apartheid in South Africa, the 'dominance of the white race' in HWU can perpetuate the view of a superior other and an 'inferior black race'. Racism and unfairness towards black students by white lecturers was also reported to be a problem in lecture rooms (Department of Education Report 2008). It can be deduced from the above that transformation of higher education is a complex, multifactorial endeavour that clearly involves the curriculum, demographics of academic staff as well as institutional cultures, which remain colonised.

\section{Understanding the identity of black students}

Identities are the traits and characteristics, social relations, roles, and social group memberships that define who one is. Identities can be focused on the past-what used to be true of one, the present-what is true of one now, or the future-the person one expects or wishes to become, the person one feels obligated to try to become, or the person one fears one may become. Identities are orienting, they provide a meaning-making lens and focus one's attention on some but not other features of the immediate context. (Leary \& Tangney 2012:69)

Hogg and Abrams add that identity also includes how one relates to the other (1988).

The main definition that this paper adopts is that of Deng (1995:1): 'the way individuals and groups define themselves and are defined by others on the basis of race, ethnicity, religion, language, and culture'. This definition is supported by Jenkins (1996:4), who defines identity as 'the ways in which individuals and collectivities are distinguished in their social relations with other individuals and collectivities'.

It can be deduced from the above definitions and description that identity reflects the image (social systems, language, culture, folklores, values, etc.) of a certain group of people. In addition, South Africa, at least, after the apartheid experience was thought of as a 'rainbow nation', meaning that it has a unique, yet colourful cultural and racial identity or identities. This adheres to Bloom's conceptions of national identity as 'that condition in which a mass of people have made the same identification with national symbols - have internalized the symbols of the nation' (Bloom 1990:52).

However, as a follow-up on Bloom's (1990) assertions on national identity, Fanon (1963) had something to say about Bloom's notion of 'National Identity', especially in a 'post'colonial nation, like South Africa.

According to Fanon (1963), as important as national identity is, in a 'post'-colonial society:

it (National Identity) inscribes an essentialist, totalizing, fetishized, often middle-class specific understanding of 'nation' rather than encouraging a nuanced articulation of an oppressed people's cultural heterogeneity across class line. p.175

In other words, although the concept of 'nation' unfairly characterises colonised subjects as historically unified in their 'primitiveness' or 'exoticness', the term's promise of solidarity and unity often proves helpful nonetheless in their attempts at 'political amelioration'. The 'political amelioration' is arguably what led to Mr Mandela and $\mathrm{Mr}$ 
Tutu's insistence on the concept of a 'rainbow nation', without a thorough and consciously coordinated strategy to ensure proper 'integration' to fully proclaim and appreciate the beauty of the rainbow. This political amelioration has instead kept intact the cultural homogeneity of different groups, a phenomenon that has affected race relations, 'post'apartheid South Africa - whose effects could be observed in HWU.

To understand the social identity of black students in HWU, we first need to understand the identity of black students. In a study with postgraduate students, black identity was associated with a dark skin colour, culture (lifestyle and practices), language, financial deprivation or poverty (Barroso 2015). When trying to understand students' identities in South Africa, Pattman (2007) discovered that students in University of KwaZulu-Natal classified themselves according to racial groups and participants significantly pointed out race as a marker of identity.

Other factors such as ethnicity, gender, religion and class contribute to the formation of the identity of black students (Pattman 2007). Regardless of the demographics of the participants, varying socioeconomic statuses, for example black people, was seen as being inferior to white people (Barroso 2015). Formal abolition of racial discrimination and segregation 'did not undercut the existential experience of blackness' (Barroso 2015:69). Being a black person is then associated with shame and struggle. Different views however exist; some participants reported associating being a black South African with pride as they reflect on surviving the struggle of apartheid (Barroso 2015). Pattman (2007) reported that some students reported feeling privileged to be at university adding that some black young people do not get an opportunity to go to university.

Frantz Fanon's definition of the identity of a black man is noted as applicable to understanding experiences of black university students (Barroso 2015). Black identity according to Frantz Fanon (1952) is said to be characterised by mimicry, double consciousness and inferiority. W.E.B. Du Bois (1903) in The Souls of Black Folk refers to this notion of double consciousness as 'a peculiar sensation'. Du Bois elaborates that 'this sense of always looking at one's self through the eyes of others, of measuring one's soul by the tape of a world that looks on in amused contempt and pity' (p.15). It is this double consciousness that makes racial or cultural integration almost impossible, as the paper shall demonstrate later.

With white identity classified as the ideal identity, black students would feel inferior to white students, and mimicry then occurs as a result. Mimicry refers to an aspiration to be white; it encompasses trying to attain the 'white culture, white language, white dress and white governance' (Barroso 2015). In Pattman's (2007) study, some black students were reported to be 'trying too hard to be white' (p. 481). The said black students are reported to use English among same ethnic group students and dress in a way that was seen as "white'".

Mimicry is sometimes unavoidable and could also illustrate the fact that the coloniser's culture can be performed in that case, mimicry could be used to undermine the 'gains' of the colonial agenda (Bhabha 1994). There are white influences that cannot be avoided, such as using the English language (Barroso 2015). In Pattman's (2007) study, some black students are reported to have used English as a universal language to communicate with others from different ethnicities. Barraso (2015) highlights the importance of assimilation into a white culture in that one needs to be socialised into the Western world to make any sense and to be taken seriously. Being socialised into the white world is said to lead to one compromising to assimilate (Barroso 2015). Black students would then have to compromise their customs, language and beliefs in order to function in the white world.

Mimicry is described to be more complex for the elite black person who is constantly torn between the need to succeed (associated with being a white person) and longing for black sameness with fellow black men (Barroso 2015). With specific regard to black students in HWI, identity is mitigated by not only institutional culture in HWI, but black people in the wider South Africa as well (Barroso 2015). Going to university is associated with aspiring to be a white person (Barroso 2015). The act of being torn apart between aspiring to be a white person and the need to fit into one's society and culture is termed double consciousness (Du Bois 1903; Fanon 1952).

Double consciousness places students in an awkward and uncomfortable positions both at the university and at home (Barroso 2015). They receive disdain when they associate with white people's sense of being both at school and in their respective black communities. Participants reported being called 'coconuts', which is a derogatory term referring to a black person who acts like a white person and has lost what it means to be a truly black person (Barroso 2015). Double consciousness brings about discrimination, isolation and frustration and may further result in black-on-black racism, especially if one is a foreigner (Barroso 2015).

Double consciousness results in recognition that there are variations between the institutional culture and societal culture at home. Institutional culture is depicted by how things are done, especially in HWU (Vincent 2015). Anticipation of a struggle of having to negotiate one's identity when at home may affect how one then negotiates one's identity in HWI. Double consciousness creates anxietyprovoking experience for black students where they do not belong anywhere: they are a 'coconut' but not a white person, and not 'black enough' because of their level of education which is associated with being a white person (Barroso 2015). The above discussion indicates identity struggles for black university students: 
Heterogeneity of black students is also a contributing factor to their identity; these differentiating factors include family background, experiences, etc. (Goldsmith 2003).

Family background is said to fuel perceptions of the white 'other' because of socialisation through apartheid stories that depict the 'bad' white 'other'. Alternative stories can be assumed to have different impacts on the identity development of black students, hence their experience of negotiating their identities in HWI. (Barroso 2015)

Experiences are mainly interactions with the white 'other' (whether directly or indirectly) that form a basis for one's perceptions of being a black person (Barroso 2015). In Barroso's (2015) study, one participant reported that she becomes aware of her blackness when she is around white students or when she has to speak English. Perception of the 'white-other' because of experiences and family background is said to be fluid and open to change and could be further reshaped by understanding the 'white-other' that changes one's perceptions of their identity as a black person (Barroso 2015). Because identities are constructed against each other, it can be then assumed that the change in perception of the 'white-other' will change one's perception and identity of being a black person.

\section{The black student from upper-middle-class socioeconomic background}

Heterogeneity of black students also has to do with varying socioeconomic statuses and social exposure to different races. According to Soudien (2007), racial mix is only seen in affluent institutions; township schools still consist of mainly black students and black teachers. Black students from lower socioeconomic class may then have to interact or come into the picture of a 'rainbow nation' when they get to universities. Middle-class black people are said to be more socially and economically privileged (Barroso 2015).

Students from middle-class backgrounds are able to access private schools at pre-university level (Franchi \& Swartz 2003). Varying socioeconomic status within black students then creates a hierarchy. Black students from lower socioeconomic class are then construed as particularly less desirable when compared to black students from middleclass families (Barroso 2015). Prior interactions with the white students by middle-class black students would mean prior chances to negotiate one's social identity around varying cultures, which might influence the way one then negotiates one's social identity in HWU and that might impact one's academic performance.

Peltzer (2002) refers to this exposure to a Westernised world through interaction with others as a Westernised personhood. According to Peltzer (2002), an African with a Westernised personhood has been integrated into a Western way of life. This person is different from a traditional personhood who has no direct influence of the Western world, and a transitional personhood who is in the process of integrating to a Western culture. Some black students from rural communities may have to manoeuvre their way from the traditional personhood through the transitional personhood to the Westernised personhood in order to fit into the institutional culture in HWU. As already mentioned, prior exposure to Western culture would be an added advantage for some students in HWU - because they turn to be more accepted, especially when they relinquish their 'real' identities and embrace the acceptable middle-class 'transformed' black student identity - which is an assimilation into the culture of the 'other'(see Bulhan 1980 Dialectic of Cultural-Inbetweenity).

Hierarchies within black students because of differences in class - hence exposure and access to private school - may contribute to a good command of the English language. A good command of the English language is reported to help one integrate better in HWU where English is the medium of communication (Barroso 2015). Language is critical as it can identify one's accent as either aspiring to be white (because of fluency in speech) or inferior because they are not fluent in English (Barroso 2015). A black person who approximates the identity of a white man, for example speaks 'better' English, will see himself or will be seen by others as better than his fellow black men (Fanon 1952). Steve Biko provides an example of this in the collection of writings: I write what I like. Biko (1986) writes:

They have been made to feel so long that for them it is comforting to drink tea, wine or beer with whites who seem to treat them as equals. This serves to boost their own ego to the extent of making them feel slightly superior to those blacks who do not get similar treatment from whites. These are sort of blacks who are a danger to the community. ( p. 23)

Other hierarchies are reported to be based on skin colour. Being light skinned is reported to be seen as being beautiful and better than having a darker skin (Barroso 2015). The lighter the skin, the closer to being a white person. Being dark skinned is considered foreign. A very dark skin is associated with other African countries, hence indicating that one does not belong. Black-on-black racism has been reported based on a darker skin colour (Barroso 2015).

Drawing from Leary and Tangney's (2012) definition above, identities of black students seem to be focused on the past the legacy of racial oppression during apartheid; the present the realities of post-apartheid South Africa reflecting a 'rainbow' nation, encouraging racial integration; and the future - the wish to succeed (associated with being a white person) with a fear of losing one's culture and heritage. Identities are a journey of self-discovery for black students, challenging both at home and at school, sometimes feeling that one does not belong anywhere, having to prove one's blackness at home and one's whiteness in HWI (Barroso 2015). Identities are fluid and not concrete and they change given different situations (Barroso 2015). In light of the above discussions, one may conclude that the historical context of South Africa contributes to the identity development of black students. 


\section{Social identity and academic achievement}

In their study with students to understand the effects of social identity on learning, Bliuc et al. (2011) found that a strong identification with the social group 'university student' was associated with deep approaches to learning. According to Bliuc et al. (2011):

It seems plausible that high identifiers with the social category university student would be more likely to be motivated to pursue learning at a deeper level, rather than just complete tasks in order to meet the requirements for the course. (p. 571)

One participant in Barroso's (2015) study mentioned that because of language barriers, one would avoid participating in class even if it means losing some marks. This example highlights instances where black students go through a social identity challenge and its possible impact on educational achievement as described by Bliuc et al. (2011).

In a different study by Fearon (2012), ethnic identity was linked to academic achievement. This study further reinforces the idea that students need some form of social identity, including academic identity to achieve academically. According to the SIT, belonging to a group and having emotional ties with the group boost one's self-concept. It is therefore understandable that students who find it difficult to fit into a social identity of the 'university student' perform poorly because of the assumed low self-concept. The social context of South Africa and the current identities of black students in HWU have been discussed. These factors play a role in whether the students feel welcome and are part of the social group 'university student' in an environment that has been discussed to be alienating and unwelcoming of black students. These environmental factors, and other factors as well, can be assumed to act as a barrier for black students to find their social identity as students, in other words, their identity as university students.

Perceptions of an unwelcoming institutional culture may further affect the well-being of black students in HWU. Bizumic et al. (2009) explain that the way students perceive the institutional culture will affect their psychological wellbeing. In this study, social identification was significantly linked to depression, anxiety, stress aggression, self-esteem and victimisation. 'Social identification as a member of the school emerges in this research as a central and significant variable in explaining individual psychological well-being' (Bizumic et al. 2009:188).

Fordham and Ogbu (1986), as cited by Vilella (2011), communicated an important point around black students' academic performance and identity. According to Ogbu, students may refuse to adapt to the mainstream culture while trying to assert their cultural identity. This is termed 'oppositional culture' and is said to explain the difference in academic achievement of black students and white students (Ogbu 1986). Black students are said to have a fear that they will be accused of being white (Ogbu 1986). This fear of being called 'white' and a need to defend one's cultural identity have been observed in South African black university students through the use of derogatory terms such as 'coconut' which have already been explained in this paper (Barrosso 2015). A black student has been reported to go through a dilemma of achieving academic excellence and maintaining their culture, which Du Bois (1903) and later Fanon (1952) termed 'double consciousness'.

\section{Social identity theory and acculturation model}

In this paper, SIT will be used to understand the experiences of black students in negotiating their social identities in HWU. SIT by Tajfel and Turner (1979) is a social psychology theory that attempts to explain group behaviour (Trepte 2006). Social identity is described as someone's self-concept in relation to a group that the person belongs to and values (Trepte 2006). A group is seen as two or more people belonging to the same social category and emotionally connected to each other (Trepte 2006). Given its focus on intergroup behaviour (Trepte 2006), SIT will be useful for understanding the social experiences of black university students.

Different theories and models have been used to understand the identities of black students. These include Fanon's idea of the colonised mind (Fanon 1952) and Biko's Black Consciousness movement (Biko 1978; Dodd 2013). Given the illustrated weight of history on the development of identity in the South African context, these approaches are important for understanding the historical development of the identity of black students. Different studies have used these approaches and demonstrated their applicability to understanding the identities of black students in South Africa (Mnguni 2000; Pattman 2007; Barroso 2015). As much as these approaches provide a historical illustration of the development of the identity of black students, they do not provide a full picture of the shape the identities of black students assume when they get into social spaces, especially in HWU.

There is a distinction between self-identity and social identity. In Barroso's (2015) study, participants were reported to have 'positive and reaffirming identities' (p. 86), but the study still showed that students struggled to socially interact with others. Positive identity development therefore does not necessarily indicate a positive social identity development. The focus of the SIT on intergroup behaviour hence provides a clearer picture of the shape that the identity of black students assumes when they get into social spaces in HWU.

Given its lack of focus on the historical development of identity (or at least not directly), the SIT provides a space to consider that not all identities will be based on and aligned with the historical legacy of South Africa. The model of acculturation by Berry (2005), similar to SIT, illustrates 
different approaches to negotiating one's social identity in a multicultural environment. In addition, unlike the SIT, the model of acculturation provides a basis for understanding a possible positive social identity beyond the factors discussed that may already render a negative social identity development for black students.

According to SIT, people strive for a positive social identity, which in turn enhances their self-esteem (Tajfel \& Turner 1979). Membership to groups is associated with negative or positive connotations, which can lead to positive or negative social identity (Tajfel \& Turner 1979). A positive social identity is because of feeling that one's group is distinct from the comparison group and it is valuable (Trepte 2006).

Negative social identity results from comparison with the out-group where one feels that one's group is inferior or insubordinate to the comparison group (Tajfel \& Turner 1979). There are several solutions to feeling inferior; these include leaving the group to join a group of higher status, comparing one's group to the out-group on a different dimension, changing values attached to the group and changing the comparison group (Trepte 2006).

As already discussed, black identity has been historically associated with negative connotations that may still exist in the post-apartheid South Africa. These negative connotations may make black students feel devalued in HWU. This is then worsened by an illustrated unwelcoming institutional culture. Studies have demonstrated the inferiority of black students in HWI (Mnguni 2000; Pattman 2007; Barroso 2015). Black students demonstrated a sense that they do not belong to and are different from the underlying institutional culture in HWU. Different factors that have already been discussed may contribute to the development of a negative social identity.

The historical context of South Africa, the resulting social segregation because of apartheid and the unwelcoming culture in HWI can all contribute to a negative social identity of black students. These factors are imposed on black students leading to a negative social identity. However, one may still consider the possibility of a positive social identity development regardless of a negating history and present alienating culture of HWI. Students may still positively negotiate their social identity despite the imposed negation of their identity.

The social identity theory therefore does not explain a situation where a group of black students, despite their feelings of being weak or insubordinate, have accepted the privilege of white students and do not seek to challenge or join any perceived powerful group. The above description is consistent with what Berry (2005) terms integration in response to multiculturalism. Integration is described as the appreciation of different cultures while still keeping one's cultural identity (Berry 2005). Integration would mean that a black student is open to learning other cultures but is still able to maintain their own values, customs and principles.
Failure to do so would mean that the student assimilates, separates or marginalises other cultures. Assimilation involves interactions with other cultures while one loses their cultural identity, separation involves avoidance of interactions with other cultures while trying to maintain one's original culture and marginalisation refers to little interest towards other cultures. Studies have shown that students assimilate, separate and marginalise other cultures, mainly the white culture (Mnguni 2000; Pattman 2007; Barroso 2015).

Integration as already mentioned has been indicated to be the ideal response to cultural differences. However, it has been noted that integration is only effective if it is done by both parties. Black students in Moodley's (2013) study indicated that they were the ones expected to integrate in HWU. This one-sided integration was envisaged and described by Steve Biko as artificial integration (Biko 1978).

\section{Artificial integration in historically white universities}

The 'rainbow nation' narrative in South Africa is predicated on the integration idea - Berry's idea of integration (2011). The rainbow nation narrative encourages the idea of the 'new' South Africa as an inclusive society. When proclaiming South Africa as a 'rainbow nation', Tshawane argues that Tutu sought 'a universal vision of inclusive humanity which transcends the barriers of race, class, tribes, ethnicity, religion and other forms of sectarianism' (2009).

'Integration' is putting together parts of elements and combining them into a whole (Integrated I Define Integrated at Dictionary.com, n.d.). The 'rainbow nation' notion when used in the 'integration' narrative means the coming together of different race groups and cultures in a multicultural and multiracial country. Integration would lead to acculturation; however, according to Biko, in South Africa, cultural or racial integration only took place between the Boers and the English (Biko 1978), and all other race and cultural groups have been forced into assimilation on terms defined by white people.

Archbishop Desmond Tutu's campaign of advancing the rainbow nation notion and calling on South Africans to celebrate diversity has fallen into deaf ears. There are certain important days in the democratic order of South Africa such as Freedom Day, Heritage Day, etc. All these days are celebrated by one group of the South African population: the black group (Segalo 2015) - arguably, this is one of the signs of lack of racial integration and social cohesion and, therefore, an indicator of a failed 'rainbow nation'.

Viewing universities as microcosm of the broader society, Berry's racial integration phenomenon becomes vivid in HWU. Because of the national government social change policies, the HWU have had to open their doors to students from black social groups. However: 
instead of aiming to shift the ruling symbolic, structural and intergroup traditions within universities, certain notions of integration, whether based on race, gender, class, sexuality or ability, assume transformation to be assimilation of blacks into an already established set of the white patriarchal regime within universities, especially HWU (authors' emphasis). (Ratele 2015:2)

Biko referred to this kind of integration as 'artificial'.

According to Biko, the talk about 'integration' in South Africa is artificial in that 'it is a response to conscious manoeuvre rather than to the dictates of the inner soul' (Biko 1986:21). Biko (1986) goes further to argue that:

the people forming the integration complex have been extracted from various segregated societies with their in-built complexes of superiority and inferiority and these continue to manifest themselves even in the non-racial set up of the integrated complex. (p. 21)

\section{According to Bourdieu:}

the cultural reproduction of knowledge and values of the economically and culturally dominant groups in society ... validate and reinforce the cultural capital that students whose cultural traits and characteristics are subordinated and/or excluded from mainstream norms experience alienation in school cultures. (Nieto 1996:284)

Hence, black students have no choice but to assimilate if they are to succeed in the HWU.

According to Fanon (1952), if a black person is overwhelmed by the 'desire to be white, it's because he lives in a society that makes his inferiority complex possible, in a society that proclaims the superiority of one race over another' (p.80). In other words, there is no racial or cultural integration; there is an assimilation that makes integration false and unrealistic, hence 'artificial'. This is due to the fact that blacks who were stripped of the 'self' have not attained that envisioned self beyond and above the terms of cultural and physical dominance as conditioned by apartheid (Hook 2004). Moreover, white people superiority complex is still intact (Biko 1986) and universities are the bastion of white supremacy, especially HWU (Ratele 2015).

Writing in the 1970s, Biko criticised integration that makes a white person a 'perpetual teacher and black a perpetual pupil'. Biko denounced the idea that white people are 'divinely appointed pace setters in progress' (Biko 1986:25). Biko argued that a country in Africa ought to reflect such African values, and if the majority is Africans in that country, that majority should determine the 'broad direction taken by the joint culture of that society' (Biko 1986:26). Owing to decades of oppressing and white racism, real integration can be achieved when black people have managed to assert themselves to a point that mutual respect has been shown' (Biko 1986:26). From such 'mutual respect for each other and complete freedom of self-determination there will obviously arise a genuine fusion of the life-styles of the various groups' (Biko 1986:22).
Therefore, higher education institutions, as it has been indicated above, reflect the social conditions of the broader South Africa, and instead of seeing black students maintaining their identities, they have assimilated, and failure to assimilate leads to social alienation. This might impact on academic performance, high dropout rate and other forms of delinquency (Kozol 1991). The 'blind' education system and institutional culture of HWI serve the 'class education' that Chancellor Williams referred to in his classic of 1974 entitled The Destruction of Black Civilization. Williams (1974) argues that this education system makes these black students foreign to their traditional communities - it replaces their identities with those of their superior masters, the white identity. It was on this basis that Biko decried a one-sided view of integration. According to Biko (1986), this meant blacks need to assimilate into 'white' society and embrace white values in order for them to be acceptable as human beings. Integration as such, argued Biko, positions 'whiteness' as a norm or standard. This form of integration, argued Biko, has to be destroyed and replaced with an aspiration for a more human content. The human content would bring about true integration where one's humanity is respected, and that is 'true integration' (Biko 1986).

\section{Biko asserts that:}

true integration is the provision of each man, each group to rise and attain the envisioned self (1986). Each group must be able to attain its style of existence without encroaching on or being thwarted by another. 'Out of this mutual respect for each other and complete freedom of self-determination there will obviously arise a genuine fusion of the life-styles of the various groups. (Biko 1986:22)

This means in order for the HWI to provide inclusive education experience for black students whose identities are less represented in these structures, these institutions must develop a greater appreciation of diversity and how this diversity could be effectively managed.

It is important to mention that, even though some have criticised and dismissed diversity management, South Africa is a multiracial and multicultural society, and black domination would be an abomination. The process of decolonisation should be accepted as it means the unmasking of the colonial without denying the existence of other race and cultural groups. As mentioned above, the modern South African university is part of the colonial project as such; decolonisation that means eradication of other race and cultural groups from the surface of South African society would engender an injustice that replicates the colonial and apartheid agenda of racial and cultural exclusion. This paper advocatesfora carefully planned and honestacknowledgement and celebration of diversity coupled with structures in place to address any feelings of alienation and exclusion.

These universities need to go beyond the legislative prescripts of inclusivity as it relates to numbers and engage seriously and meaningfully with diversity management. Affirmative action must be acknowledged as the process that creates 
diversity that must then be managed. Norris (cited in Havenga 1993) explains this process of diversity management by asserting that:

diversity starts with a realization of diverse interests ... unlike affirmative action which is a process for creating diversity, that the very essence of the institution and its culture must be renegotiated and re-conceptualized from a perspective other than the dominant culture. (Norris 2001:219)

It is important for universities to deal with this because as studies have proven, the current structures in HWI contribute to black students' social alienation and academic progress or lack thereof.

It then appears as if Berry's (2005) integration is difficult to negotiate and most students find themselves assimilating or avoiding contact with other cultures. It also appears that what instead we have in HWI is the 'artificial integration' that Biko referred to, where cultural convergence towards a dominant 'white' identity is encouraged (Biko 1978). The question then is: what can universities do to help students with the integration process?

\section{Conclusion and recommendations}

The social identities of black students have been discussed in this paper. Available research on black South African university students has highlighted social identity challenges especially in HWU. The social context of South Africa that suggests racial segregation especially in rural areas (where some black students come from) and the institutional culture in HWU have been proved to harbour issues that affect the social identity of black students. HWU have been described to be unwelcoming and alienating of black students' social identities, contributing to the challenge of social identity negotiation. Several studies have linked social identity to academic performance. These studies highlight that students have to identify socially with the identity of 'university students' for them to perform well academically. Adjustment issues, including identity negotiating, have been highlighted to affect the psychological well-being of students.

Given the effect of social identity issues on both the academic performance and psychological well-being of black students, it is important for HWU to be sensitive to such issues. Based on Vincent's (2015) definition of institutional culture as both the material and discourses in a university, universities should make an effort to be sensitive to the issues surrounding the identity of black students and how they approach learning because of these, both on a material and a discourse level.

Historically white universities should also assist in breaking discourses around an 'inferior black' and the 'ideal white'. Such discourses have a heavy historical component that situates black students as the stranger in HWU. Open conversations around such issues should be facilitated in order to hear from black students what assistance they need to make spaces HWU welcoming. Vilella (2011) suggested implementing cultural awareness programmes that allow students to learn about each other's cultures and practices. This involves creating less-threatening spaces where students can interact with and learn about each other. This is said to assist in disconfirming some of the assumptions about other races that contribute to racial segregation (Vilella 2011).

Existing transformation policies should also be revisited and evaluated in terms of their feasibility and how they can be presented in a way that is sensitive to issues around identity and the continuation of discourses of an inferior black student. In Moddley's (2013) study, racial admissions as part of transformation policies in Cape Town contributed to black students feeling 'othered' by white students and 'othering' white students as a result. Black students are reported to have further felt they have only been admitted on the basis of their race and therefore are not deserving to be in the university (Moodley 2013). This study highlighted possible challenges with available transformation policies that will need to be evaluated.

Universities, especially HWU, which are discussed in this article should 'stop and question' available policies, programmes and course structure, reviewing whether they are inclusive or exclusive of black students' identity challenges. Policies that continue to alienate black students' identities should be questioned and revised. Upon revising of available policies, there should also be implementation of programmes designed to help black students adjust to a different environment in HWU (Bliuc et al. 2011). Such programmes should be designed to help students who may experience culture shock and adjustment problems upon enrolling into HWU.

Other than evaluation of discourses, materials within HWU also need to be assessed. Another task by HWU would be to identify specific materials within the institutional culture that contribute to the alienation of black students. Factors such as the use of fork and knives hint to possibilities of creating certain spaces within the university to be welcoming and inviting for students from different backgrounds and cultures. HWU should ask questions such as the following: where in this university can a black student from a rural area be comfortable to sit and feel at home?

Further research on the identity of black students is recommended specifically on what makes the black student thrive in HWU. Research that compares the identity of black students who perform well with those who perform poorly will help identify protective factors that will inform programmes to help integrate black students into HWU. Research also helps to direct policy and programme development (Fearon 2012).

\section{Acknowledgements Competing interests}

The authors declare that they have no financial or personal relationships which may have inappropriately influenced them in writing this article. 


\section{Authors' contributions}

S.B. was the supervisor of the study and wrote some sections of the study. He also submitted the paper and responded to some reviewers' comments. P.M wrote most of the parts of the literature review. She did most of the responding to the reviewers' comments and suggestions.

\section{References}

Badat, S., 2010, 'The challenges of transformation in higher education and training institutions in South Africa', paper commissioned by the Development Bank of Southern Africa, viewed 13 June 2016 , from https://www.ru.ac.za/.../The $\% 20$ Challenges $\% 20$ of $\% 20$ Transformation $\% 20$ in $\% 20 \mathrm{High}$

Barroso, A.K.M., 2015, A critical Fanonian understanding of Black student identities at Rhodes University, South Africa, Rhodes University, Grahamstown.

Berg, A., 2012, Connecting with South Africa: Cultural communication and understanding, 1st edn., Texas A\&M University Press, College Station, TX.

Berry, J.W., 2005, 'Acculturation: Living successfully in two cultures', Internationa Journal of Intercultural Relations 29(6), 697-712. https://doi.org/10.1016/j. ijintrel.2005.07.013

Bhabha, H., 1994, The location of culture, Routledge, London.

Biko, S., 1986, I write what I like, Harper \& Row, San Francisco, CA.

Bizumic, B., Reynolds, K.J., Turner, J.C., Bromhead, D. \& Subasic, E., 2009, 'The role of the group in individual functioning: School identification and the psychological well-being of staff and students', Applied Psychology 58(1), 171-192. https://doi. org/10.1111/j.1464-0597.2008.00387.x

Bliuc, A.M., Ellis, R.A., Goodyear, P. \& Hendres, D.M., 2011, 'The role of socia identification as university student in learning: Relationships between students' social identity, approaches to learning, and academic achievement', Educationa Psychology 31(5), 559-574. https://doi.org/10.1080/01443410.2011.585948

Bloom, W., 1990, Personal identity, national identity and international relations, Cambridge Studies in International Relations. (No. 9), Cambridge University Press, Cambridge.

Bojuwoye, O., 2002, 'Stressful experiences of first year students of selected universities in South Africa', Counselling Psychology Quarterly 15(3), 277-290. https://doi.org/10.1080/09515070210143480

Bulhan, H., 1980, 'Dynamics of cultural in-betweenity: An empirical study', International Journal of Psychology 152, 105-121. https://doi.org/10.1080/0020 7598008246986

Collins, K. \& Millard, M., 2013, 'Transforming education in South Africa: Comparative perceptions of a South African social work learning experience', Educational Review 65(1), 70-84. https://doi.org/10.1080/00131911.2011.648168

Crais, C.C., 1992, White supremacy and Black resistance in pre-industrial South Africa the making of the colonial order in the Eastern Cape, 1770-1865, Cambridge University Press, UK.

Cutten, M., 1987, Natal University and the question of autonomy, 1959-1962, Natal University, Durban, South Africa.

Deng, F.M., 1995, War of visions: Conflict of identities in the Sudan, Brookings, Washington, DC.

Department of Education, 2008, Report of the ministerial committee on transformation and social cohesion and the elimination of discrimination in public higher education institutions, Final Report, Department of Education, Pretoria.

Dodd, N. \& Snelgar, R., 2013, 'Core self-evaluations and Black consciousness in postapartheid Zululand, South Africa', The Journal of Psychology 4(2), 101-107.

Du Bois, W.E.B., 1903, The Souls of Black Folk, A.C. McClurg \& Co., Chicago, IL.

Evans, J., 2016, What is decolonised education?, viewed 22 August 2017, from http:// www.news24.com/SouthAfrica/News/what-is-decolonised-education-20160925.

Fanon, F., 1952, Black skin, white masks, transl. R. Philcox, Grove Press, New York.

Fanon, F., 1963, The wretched of the earth, Grove Press, New York.

Fearon, D.D., 2012, Identity correlates of academic achievement: How influential are self, academic and ethnic identity statuses among college students? viewed from https://baylor-ir.tdl.org/baylor-ir/handle/2104/8541.

Finchilescu, G., Tredoux, C., Mynhardt, J., Pillay, J. \& Muianga, L., 2007, 'Accounting for lack of interracial mixing amongst South African university students', South African Journal of Psychology 37(4), 720-737. https://doi.org/10.1177/ 008124630703700404

Fiske, E. \& Ladd, H., 2006, 'Racial equity in education: How far has South Africa come', Perspectives in Education 24(2), 95-108.

Fordham, S. \& Ogbu, J.U., 1986, 'Black students' school success: Coping with the "burden of 'acting white'"', The Urban Review 18, 176-206. https://doi.org/ 10.1007/BF01112192

Foster, D., 1991, "'Race" and racism in South African psychology', South African Journal of Psychology 21(4), 203-209. https://doi.org/10.1177/0081246391 02100402

Franchi, V. \& Swart, T.M., 2003, 'From apartheid to affirmative action: The use of "racial" markers in past, present and future articulations of identity among South African students', International Journal of Intercultural Relations 27(2), 209-236. https//doi:10.1016/S0147-1767(02)00093-7
Gibson, N.C., 2012, 'What happened to the "Promised Land"? A Fanonian perspective on post-apartheid South Africa', Antipode 44(1), 51-73. https://doi.org/10.1111/ j.1467-8330.2010.00837.x

Goldschmidt, M.M., 2003, 'Identifying labels among university students in the New South Africa: A retrospective study', Journal of Black Studies 34(2), 204-221. https://doi.org/10.1177/0021934703255314

Goldsmith, P., 2003, 'Race relations and racial patterns in schools sports participation', Sociology of Sport Journal 20, 147-171.

Greyling, S., 2007, 'Rhodes University during the segregation and apartheid eras, 1933 to 1990, unpublished master's thesis, Rhodes University, South Africa.

Habib, A., 1997, 'South Africa-the rainbow nation and prospects for consolidating democracy', African Journal of Political Science/Revue Africaine de Science Politique 2(2), 15-37.

Hannaway, D.A.M., 2012, 'The influence of ecosystemic factors on Black student teachers' perceptions and experiences of Early Childhood Education', MEd dissertation, University of Pretoria, Pretoria.

Havenga, A.J., 1993, 'Beyond affirmative action there is diversity', PRO Technida 10, 9-17.

Heleta, S., 2016, 'Decolonisation of higher education: Dismantling epistemic violence and Eurocentrism in South Africa', Transformation in Higher Education 1(1), 1-8. https://doi.org/10.4102/the.v1i1.9

Hogg, M. \& Dominic, A., 1988, Social identifications: A social psychology of intergroup relations and group processes, Routledge, London.

Hook, D., Mkhize, N., Kiguwa, P. \& Collins, A., (eds,), 2004, Critical psychology, University of Cape Town Press, Cape Town.

Hook, D., 2004, LSE Research Online, viewed from https://www.researchgate.net/ profile/Derek_Hook2/publication/30521167_Frantz_Fanon_Steve_Biko_ 'psychopolitics'_and_critical_psychology/links/5517fedd0cf2d70ee279775a.pdf.

Integrated, Define Integrated at Dictionary.com, viewed 17 October 2016, from http://www.dictionary.com/browse/integrated

Jenkins, R., 1996, Social identity, Routledge, London.

Khunou, S.F., 2009, 'Traditional leadership and independent Bantustans of South Africa: some milestones of transformative constitutionalism beyond Apartheid", PER: Potchefstroomse Elektroniese Regsblad 12(4), 81-122.

Kleintjes, S.R., 1991, Black clinical psychology interns at a 'white' university: Their experience of colour during training, University of Cape Town, viewed n.d., from https://open.uct.ac.za/handle/11427/13536

Kozol, J., 1991, Savage inequalities: Children in America's schools, Crown, New York.

Leary, M.R. \& Tangney, J.P. (eds.), 2012, Handbook of self and identity, 2nd edn., Guilford Press, New York.

Lefko-Everett, K., Lekalake, R., Penfold, E. \& Rais, S., 2010, SA Reconciliation Barometer Survey Report 2010 (an annual publication of the institute for justice and reconciliation), African Minds, viewed from http://www.ijr.org.za/uploads/SA reconciliation), African Minds, viewed from http://WwW.ijr.org.zatiation_Barometer_10th_Round_Report_web_FINAL.pdf

Nieto, S., 1996, Affirming diversity: The sociopolitical context of multicultura education, 2nd edn., Longman, White Plains, NY.

Macupe, B., 2016, Make blacks feels at home [Newspaper website], viewed from http://www.sowetanlive.co.za/news/2016/03/06/make-blacks-feel-at-home

Matthews, S., 2015, 'Being at home: Race, institutional culture and transformation at South Africa higher education institutions', in P. Tabensky \& S. Matthews (eds.), White privilege and institutional culture at South Africa higher education institutions, pp. 72-95, University of Kwa-Zulu Natal Press, Pietermaritzburg.

Mbembe, A., 2016, 'Decolonizing the university: New directions', Arts and Humanities in Higher Education 15(1), 29-45. https://doi.org/10.1177/14740222 15618513

McKinney, C. \& Soudien, C., 2010, 2010 IALEI Country Report: Multicultural education in South Africa, viewed from http://website.education.wisc.edu/inei/wp-content/ uploads/Documents/NP-SA.pdf

Mda, Z., 1994, 'The role of culture in the process of reconciliation in South Africa', paper presented at the Centre for the Study of Violence and Reconciliation, Seminar No. 9, 30 November.

Meier, C. \& Hartell, C., 2009, 'Handling cultural diversity in education in South Africa', South African Journal of Education 6(2), 180-192.

Mnguni, M.M., 2000, 'The role of black consciousness in the experience of being black in South Africa: The shaping of the identity of two members of AZAPO', unpublished masters thesis, Rhodes University, Grahamstown.

Mnguni, L., 2016, White privilege at the heart of battle [Newspaper website], viewed from http://www.sowetanlive.co.za/news/2016/03/02/white-privilege-at-heartof-battle

Moletsane, R., Hemson, C. \& Muthukrishna, A., 2004, 'Educating South African teachers for the challenge of school integration: Towards a teaching and research agenda', in Nkomo, M, McKinney, C \& Chisholm, L. (eds.), Reflections on school integration: Colloquium Proceedings, pp. 61-77, HSRC Press, Pretoria.

Moodley, J., 2013, She broke my identity into invisible pieces: Transformation and black students in higher education, University of Capetown, viewed from http:// www.careers.uct.ac.za/sites/default/files/image_tool/images/117/Joy.Moodley. pdf

Moore, T.O., 2005, 'A Fanonian perspective on double consciousness', Journal of Black Studies 35(6), 751-762. https://doi.org/10.1177/0021934704263839

National Planning Commission (NPC), 2011, Diagnostic overview, The Presidency, Republic of South Africa, Pretoria. 
Norris, B.D., 2001, 'Transformation, diversity and organizational change within institutions of higher education', South African Journal of Education 21(4) 219-222.

Pattman, R., 2007, 'Student identities, and researching these, in a newly "racially" merged university in South Africa', Race Ethnicity and Education 10(4), 473-492. https://doi.org/10.1080/13613320701658480

Peltzer, K., 2002, 'Personality and person perception in Africa', Social Behavior and Personality: An International Journal 30(1), 83. https://doi.org/10.2224/sbp.2002. 30.1.83

Petersen, I., 2006, Psychosocial factors and academic performance among first-yea financial aid students: Testing adjustment as a mediator variable, University of Cape Town, Cape Town.

Phoenix, A., 2009, 'De-colonising practices: Negotiating narratives from racialised and gendered experiences of education', Race Ethnicity and Education 12(1), 101-114. https://doi.org/10.1080/13613320802651053

Pilane, P., 2014, Does a lecturer's race matter to university students?, viewed from http://www.thedailyvox.co.za/does-a-lecturers-race-matter-to-universitystudents/

Rafaely, D., 2014, 'Transforming psychology: English language in practice', New Voices in Psychology 10(2), 28-42.

Ratele, K., 2015, 'Is university transformation the assimilation of black into an already established set of white patriarchal capitalist traditions?', Paper presented at the University of Pretoria's Critical Conversation on Transformation, Pretoria, 13 August.

Righi, R.A., 2012, The impact of laptop computers on student learning behaviors as perceived by classroom teachers, University of Toledo, viewed from http://rave. ohiolink.edu/etdc/view?acc num=toledo1333741245

Schrieff, L.E., Tredoux, C.G., Finchilescu, G. \& Dixon, J.A., 2010, 'Understanding the seating patterns in a residence-dining hall: A longitudinal study of intergroup contact', South African Journal of Psychology 40(1), 5-17. https://doi.org/ $10.1177 / 008124631004000102$

Segalo, P., 2015, 'Gender, social cohesion and everyday struggles', Psychology in Society 49, 70-82. https://doi.org/10.17159/2309-8708/2015/n49a6

Soudien, C., 2007, Youth identity in contemporary South Africa: Race, culture and schooling, New Africa Books, Cape Town.

South African Human Rights Commission, 2016, Transformation at public universities in South Africa, SAHRC Report, South African Human Rights Commission, Cape Town.
Steyn, M.G., Harris, T. \& Hartell, C.G., 2014, 'Institutional factors that affect black South African students' perceptions of Early Childhood Teacher Education', South African Journal of Education 34(3), 1-7. https://doi.org/10.15700/ South

Tajfel, H. \& Turner, J., 1979, 'An integrative theory of intergroup conflict', in W.G. Austin \& S. Worchel (eds.), The social psychology of intergroup relations, W.G. Austin \& S. Worchel (eds.), The
pp. 33-48, Brooks-Col, Monterey, CA.

The South African Reconciliation Barometer Survey, 2010, SA Reconciliation Barometer Survey Report, Institute for Justice and Reconciliation, viewed 29 September, from https://sabarometerblog.files.wordpress.com/2011/03/sa-reconciliationbarometer-10th-round-report-web-final.pdf

Tshawane, N.J., 2009, 'The rainbow nation: A critical analysis of the notions of community in the thinking of Desmond Tutu', unpublished doctoral dissertation, University of South Africa.

Trepte, S., 2006, 'Social identity theory', in J. Bryant \& P. Vorderer (eds.), Psychology of Entertainment, pp. 255-271, Lawrence Erlbaum Associates United Nations, Mahwah, NJ.

Vilella, A., 2011, The relationship between ethnicity and academic achievement October 19th, 2011, viewed from http://www.ccsj.edu/news/ncate/Standard4/ 4exhibits/diversityreflec.pdf

Vincent, L., 2015, 'Being at home: Race, institutional culture and transformation at South Africa higher education institutions', in P. Tabensky \& S. Matthews (eds.), Tell us a new story: A proposal for the transformatory potential of collective memory projects, pp. 21-71, UKZN Press, Pietermaritzburg.

Williams, C.W., 1974, The Destruction of Black Civilization: Great Issues of a Race Between 4500 B.C. and 2000 A.D, Third World Press, Chicago, IL.

Wingfield, B., n.d., What "decolonised education" should and shouldn't mean, viewed 22 August 2017, from http://theconversation.com/what-decolonised-educationshould-and-shouldnt-mean-72597

Withnall, A., 2016, 'Black South Africans hit out at suggestion rise in white poverty means "now there is equality"', The Independent, viewed from http://www. independent.co.uk/news/world/africa/south-africa-white-poverty-risinginequality-black-townships-apartheid-a7347116.html

Young, C. \& Campbell, M., 2014, 'Student wellbeing at a university in post-apartheid South Africa: A comparison with a British university sample using the GP-CORE measure', British Journal of Guidance \& Counselling 42(4), 359-371. https://doi. org/10.1080/03069885.2013.779638 